\title{
Analysis of Glycemic Control and Low-Density Lipoprotein Cholesterol with Glaucomatous Optic Neuropathy as a Microvascular Complication in Patients with Type 2 Diabetes Mellitus: A Cross-sectional Study in North Sumatera, Indonesia
}

\author{
Masitha Dewi Sari ${ }^{1 *}$ (D) Rina Amelia ${ }^{2}$ iD , Aryani A. Amra ${ }^{1}$ (D) \\ ${ }^{1}$ Department of Ophthalmology, Faculty of Medicine, Universitas Sumatera Utara, Medan, Indonesia; ${ }^{2}$ Department of Community \\ Medicine, Faculty of Medicine, Universitas Sumatera Utara, Medan, Indonesia
}

Introduction

The prevalence of type 2 diabetes mellitus (DM) has increased markedly in Asian countries and more than $60 \%$ of global diabetic population [1]. DM is an important health problem that induces complications and it causes significant morbidity due to specific microvascular complications such as retinopathy, nephropathy, and neuropathy [2], [3].

According to the latest International Diabetes Federation (IDF) figures, there are currently 463 million people living with DM and the total is expected to rise 700 million by 2045. In Indonesia, according to IDF there are 9.1 million people living with DM in 2014 and total is expected to rise 14.1 million in 2035. Vascular complications will affect autoregulation of the retina and optic nerves, causing reduced blood flow to the eye, and impaired oxygen dysfunction to the eye. This condition caused hypoxia and ischemic damage to the ganglion cells and the optic nerve which results in glaucoma [4], [5], [6].

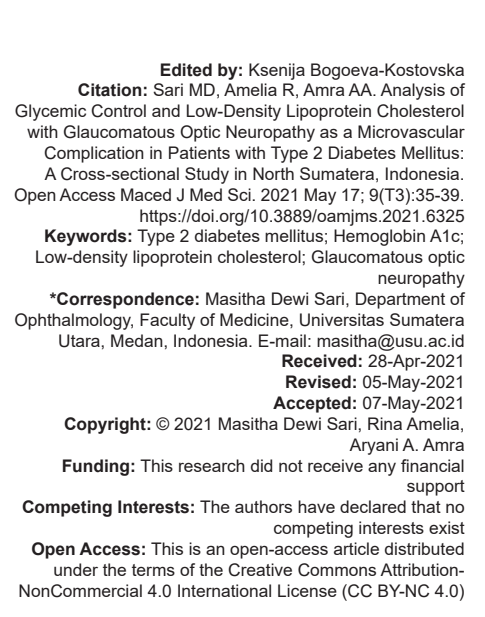

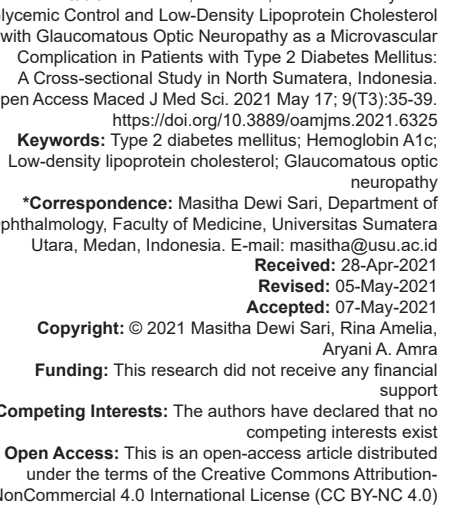

Open Access Maced J Med Sci. 2021 May 17; 9(T3):35-39

\begin{abstract}
BACKGROUND: Diabetes mellitus (DM) is an important health problem that induces microvascular complication
Abstract
BACKGROUND: Diabetes mellitus (DM) is an important health problem that induces microvascular complication such as retinopathy, nephropathy, and neuropathy. Ocular complications associated with type 2 DM are progressive AIM: This study to analyze of glycemic control and low-density lipoprotein cholesterol (LDL-C) with glaucomatous

Universitas Sumaterive analytical observational with cross-sectional study was conducted in study included 66 participants with type $2 \mathrm{DM}$. The patients were investigated for hemoglobin A1c $(\mathrm{HbA} 1 \mathrm{c})$ level, Goldmann Applanation Tonometer, retinal nerve fiber layer (RNFL) thickness with spectral domain Optovue

RESULTS: This study showed a significant correlation between HbA1c with VA ( $p=0.030)$, IOP $(p=0.035)$, RNFL CONCLUSION: Higher HbA1c and LDL-C correlated with Glaucomatous Optic Neuropathy as a microvascular complication in type $2 \mathrm{DM}$. Advantage of research is still rarely studied. and rapidly becoming the world's most significant cause of morbidity and preventable with early detection and timely optic neuropathy as a microvascular complication in patients with type 2 DM. thickness $(p=0.002)$, visual field defect $(p=0.032)$, and duration of DM $(p=0.003)$ and showed significant correlation
between LDL-C with VA $(p=0.048)$, IOP $(p=0.006)$, and duration of DM $(p=0.042)$.
\end{abstract}

Glaucomatous optic neuropathy is characterized by progressive loss of retinal ganglion cells and their axons and lead to measurable structural and functional damage to optic nerve, visual impairment, and elevated intraocular pressure (IOP) are one of the primary risk factor [7]. Glaucoma is one of the leading cause of worldwide irreversible blindness [8]. By year 2020 , it is estimated that worldwide prevalence of glaucoma will approach 80 million being bilaterally blind from glaucoma. In Indonesia, based on the results of Riset Kesehatan Dasar, the prevalence of glaucoma in 2007 was $0.5 \%$ and according to an eye health survey by the Ministry of Health of Republic Indonesia in 1993-1996, it shows glaucoma was the second cause of blindness after cataract estimated 0.2\% [9], [10].

It has not been determined definitely whether there is a significant association between DM and glaucoma. Some population based study has shown a positive association between DM and glaucoma, and other hands have shown negative association between DM and glaucoma. However, in many studies 
that showed a lack of a significant association between diabetes and glaucoma [11], [12]. Some authorities believe that small-vessel involvement in diabetes may cause the optic nerve to become more susceptibility to pressure-related damage but it is not known whether variations in glucose levels could lead IOP changes [12].

Hyperglycemic conditions in DM cause structural damage to the endothelium and retinal blood vessel tight junctions which can lead to increased systolic blood, microalbuminuria, and lipid profile. Patients with DM have lipid profiles that appear more benign than those other high risk people without diabetes [13], [14]. But in fact, the most common lowdensity lipoprotein cholesterol (LDL-C) level in DM is "borderline high" (130-159 mg/dl). This condition can initiate atherosclerotic and apoptosis vascular smooth muscle in existing atherosclerotic lesions [14]. Several studies reported a correlation between serum lipids and the incidence of glaucoma, but the correlation between glycemic control and serum lipids with glaucomatous optic neuropathy in patients with type 2 diabetes has never been found. As the diabetes and glaucoma coexist in many patients, we though to analyze the glycemic control hemoglobin A1c (HbA1c) and LDL-C with glaucomatous damage as a microvascular complication in type 2 DM in Indonesian population.

\section{Materials and Methods}

This was an analytical prospective with cross-sectional study comprising 66 type 2 DM patients. Type 2 DM patients referred from Internal Medicine Department. These subjects were recruited consecutively at Universitas Sumatera Utara Hospital, North Sumatera, Indonesia, and Satellite hospital from April 2020 to August 2020 and approved by Medical Faculty University Sumatera Utara Ethics Committee. Written informed consent was obtained from all participants. The inclusion criteria in this study were type 2 DM and approved the consent form. The exclusion criteria in this study were type 2 DM patients with anterior segment infection, cataracts, and diabetic retinopathy, and use topical and oral steroid.

The primary data of patients such as age, gender, use of medications, blood pressure and duration of type $2 \mathrm{DM}$, visual acuity (VA), IOP and time of IOP measurement, visual field defect, and retinal nerve fiber layer (RNFL) thickness were documented. The participants were investigated for $\mathrm{HbA} 1 \mathrm{c}$ and lipid profile examinations. The IOP measurement with Goldmann Applanation Tonometer Haag Streit (R900), Visual Field Defect with Octopus Perimeter (APST100), and RNFL with spectral domain (SD) Optovue optical coherence tomography (OCT) to detect the risk of glaucomatous optic neuropathy.

\section{RNFL analysis}

All participants had their RNFL measured by SD Optovue OCT. The use of SD-OCT has the potential to become an important tool for assessing glaucoma progression with the sensitivity of $83 \%$ and a specificity of $88 \%$ [15].

$\mathrm{HbA1c}$ measurement using $\mathrm{HbA1c}$ kit with high performance liquid chromatography methods [16]. Based on Indonesian Association of Endocrinology classification of $\mathrm{HbA} 1 \mathrm{c}$ level divided of two groups: $\mathrm{HbA} 1 \mathrm{c}<6.5 \%$ indicate good glycemic control and $\mathrm{HbA} 1 \mathrm{C} \geq 6.5 \%$ indicate poor glycemic control. Diabetes was defined as $\mathrm{HbA} 1 \mathrm{C} \geq 6.5 \%$ and pre-diabetes was classified as $\mathrm{HbA} 1 \mathrm{c}$ between $5.7 \%$ and $6.4 \%$ [5].

LDL-C measurement using homogeneous assay methods, according to ATP III Guidelines classification of LDL-C level divided of five groups: Optimal LDL <100 mg/dl, near optimal LDL 100-129 $\mathrm{mg} / \mathrm{dl}$, borderline high LDL 130-159 mg/dl, high LDL 160-189 mg/dl, and very high LDL >189 mg/dl [17].

\section{Statistical analysis}

The collected data kept in computer analyzed using Statistical Package for the Social Science version 22.0 in all participant and an analytical statistic using Chisquare test and Pearson test to analyze the correlation $\mathrm{HbA1c}$ level and LDL-C level with glaucomatous optic neuropathy as a microvascular complication in type 2 DM. $p<0.05$ was considered significant.

\section{Results}

The sample of this study included 66 patients recruited from Glaucoma Department, Universitas Sumatera Utara Hospital and Satellite Hospital, Medan, Indonesia. The majority of patients are woman (71.2\%), age 43-79 years old (56.42 \pm 7.153$)$, duration of type 2 DM 2-15 years (7.29 \pm 4.187$)$, VA (LogMar) 0.0-1.3 (0.58 \pm 0.4347), IOP $10-30 \mathrm{mmHg}(16.94 \pm 5.239)$, cup-to-disc ratio (CDR) 0.3-0.9 (0.55 \pm 0.148$)$, RNFL $40-129 \mathrm{~nm}(78.17 \pm 22.134)$, and mean deviation (MD) 28.44-0.08 dB (-9.65 \pm 6.411$),$ HbA1c 5.0-13.4\% (8.53 \pm 2.387 ), lipid profile level high-density lipoprotein (HDL) $24-73 \mathrm{md} / \mathrm{dl}(47.75 \pm 11.951)$, LDL51-249 mg/dl (127.00 \pm 37.307), total cholesterol 136-340 mg/dl (222.02 \pm 44.619), and triglycerides 77-408 mg/dl (247.67 \pm 139.986). Diagram characteristic of participant is shown in Diagram 1.

Distribution of the characteristic study subject is shown in Table 1. Correlation $\mathrm{HbA} 1 \mathrm{c}$ level with VA, IOP, CDR, RNFL, MD, and duration of type $2 \mathrm{DM}$ is shown in Table 1. 


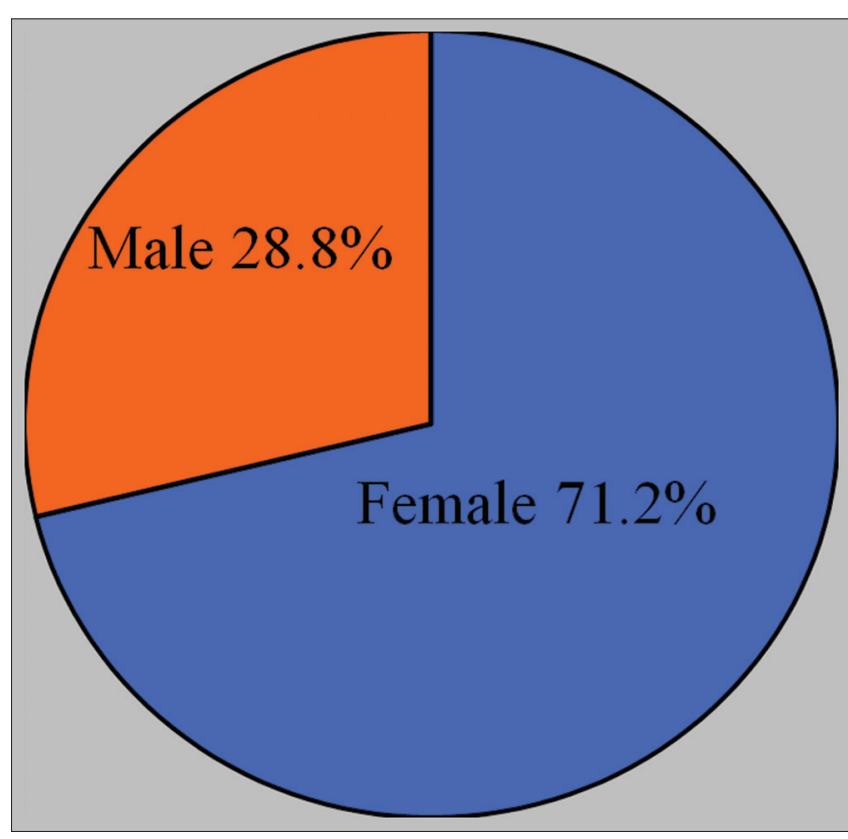

Diagram 1: Characteristic sex of participant

Table 1: Distribution of the characteristic study subject

\begin{tabular}{llll}
\hline Characteristic & $\mathrm{n}$ & Mean \pm SD & Min-Max \\
\hline Age & 66 & $56.86 \pm 6.796$ & $43-79$ \\
VA (LogMAR) & 66 & $0.58 \pm 0.4898$ & $0.0-1.3$ \\
IOP (mmHg) & 66 & $17.09 \pm 5.116$ & $10-30$ \\
CDR & 66 & $0.55 \pm 0.1480$ & $0.3-0.9$ \\
RNFL (nm) & 66 & $78.17 \pm 22.134$ & $40-129$ \\
MD Perimetri (dB) & 66 & $-9.65 \pm 6.411$ & $-28.44-0.08$ \\
PSD Perimetri (dB) & 66 & $11.38 \pm 7.960$ & $0.00-26.83$ \\
HbA1c (\%) & 66 & $8.53 \pm 2.387$ & $5.0-13.4$ \\
HDL mg/dl) & 66 & $47.45 \pm 11.951$ & $24-73$ \\
LDL (mg/dl) & 66 & $127.00 \pm 37.307$ & $51-249$ \\
Total cholesterol (mg/dl) & 66 & $222.02 \pm 44.619$ & $136-340$ \\
Triglicerida (mg/dl) & 66 & $247.67 \pm 139.986$ & $77-408$ \\
Duration of DM type 2 & 66 & $7.05 \pm 3.339$ & $2-15$ \\
\hline VA: Visual acuity, IOP: Intraocular pressure, CDR: Cup-to-disc ratio, RNFL: Retinal nerve fiber layer,
\end{tabular}
lipoprotein, LDL: Low-density lipoprotein, DM: Diabetes mellitus.

Table 2 shows the HbA1c level on VA, IOP, CDR, RNFL thickness, MD, and duration of diabetes. With Chi-square test, the $p$-value varies and is

Table 2: Correlation HbA1c level with VA, IOP, CDR, RNFL, Perimetri MD, and duration of DM Type 2

\begin{tabular}{|c|c|c|c|c|}
\hline \multirow[t]{3}{*}{ Variable } & \multicolumn{3}{|l|}{$\mathrm{HbA1c}$} & \multirow[t]{3}{*}{$p$} \\
\hline & $\mathrm{HbA} 1 \mathrm{c}<6.5$ & $\mathrm{HbA} 1 \mathrm{c} \geq 6.5$ & Total & \\
\hline & $\mathrm{n}(\%)$ & n (\%) & $\mathrm{n}(\%)$ & \\
\hline \multicolumn{5}{|l|}{ VA } \\
\hline$-0.2-0.1$ & $7(35.0)$ & $13(65.0)$ & $20(100.0)$ & \multirow[t]{4}{*}{$0.030^{*}$} \\
\hline $0.2-0.5$ & $4(28.6)$ & $10(71.4)$ & $14(100.0)$ & \\
\hline $0.6-0.9$ & $3(27.3)$ & $8(72.7)$ & $11(100.0)$ & \\
\hline $1.0-1.3$ & $3(14.3)$ & $18(85.7)$ & $21(100.0)$ & \\
\hline \multicolumn{5}{|l|}{ IOP } \\
\hline$<21 \mathrm{mmHg}$ (Normal) & $17(36.2)$ & $31(64.6)$ & $48(100.0)$ & \multirow[t]{2}{*}{$0.003^{*}$} \\
\hline$>21 \mathrm{mmHg}$ (High) & 0 & $18(100.0)$ & $18(100.0)$ & \\
\hline \multicolumn{5}{|l|}{ CDR } \\
\hline Normal: $0.2-0.3$ & $4(100.0)$ & 0 & $4(100.0)$ & \multirow[t]{4}{*}{$0.005^{*}$} \\
\hline Mild: $0.3-0.5$ & $9(23.7)$ & $29(76.3)$ & $38(100.0)$ & \\
\hline Moderate: $0.6-0.7$ & $3(15.8)$ & $16(84.2)$ & $19(100.0)$ & \\
\hline Severe: $0.8-1.0$ & $1(20.0)$ & $4(80.0)$ & $5(100.00)$ & \\
\hline \multicolumn{5}{|l|}{ RNFL } \\
\hline Normal: >80 nm & $11(50.0)$ & $11(50.0)$ & $22(100.0)$ & \multirow[t]{3}{*}{$0.004^{*}$} \\
\hline Borderline: 70-79 nm & $4(20.0)$ & $16(80.0)$ & $20(100.0)$ & \\
\hline Outside normal: $<60 \mathrm{~nm}$ & $2(8.3)$ & $22(91.7)$ & $24(100.0)$ & \\
\hline \multicolumn{5}{|l|}{ MD Perimetri } \\
\hline Mild: >-6dB & $10(34.5)$ & $19(65.5)$ & $29(100.0)$ & \multirow[t]{3}{*}{$0.032^{*}$} \\
\hline Borderline: $-12<\mathrm{MD}<-6$ & $3(25.0)$ & $9(75.0)$ & $12(100.0)$ & \\
\hline Severe: $<-12 \mathrm{~dB}$ & $4(16.0)$ & $21(84.0)$ & $25(100.0)$ & \\
\hline \multicolumn{5}{|l|}{ Duration of DM } \\
\hline $\mathrm{DM} \leq 5$ years & $10(45.5)$ & $12(54.5)$ & $22(100.0)$ & \multirow[t]{3}{*}{$0.013^{*}$} \\
\hline DM 6-10 years & $7(21.2)$ & $26(78.8)$ & $33(100.0)$ & \\
\hline$D M>10$ years & 0 & $11(100.0)$ & $11(100.0)$ & \\
\hline
\end{tabular}

RNFL: Retinal nerve fiber layer, MD: Mean deviation, DM: Diabetes mellitus. at $p<0.05$, which means that there is a significant correlation between levels of $\mathrm{HbA} 1 \mathrm{c}$ on VA, IOP, RNFL, $\mathrm{MD}$, and duration of type $2 \mathrm{DM}$.

Correlation LDL-C level with VA, IOP, CDR, RNFL, MD, and duration of DM is shown Table 3.

Table 3 shows the LDL-C level on VA, IOP, CDR, RNFL, MD, and duration of DM. With Chi-square test, the $p$-value varies and is at $p<0.05$, which means that there is a significant correlation between increased levels of LDL-C on VA, IOP, MD, and duration of type $2 \mathrm{DM}$.

Correlation $\mathrm{HbA1c}$ level and LDL-C level with VA, IOP, CDR, RNFL, MD, and duration of type 2 DM is shown in Table 4.

Table 4 shows positive and significant correlation of Hba1c level on VA $(r=0.267, p=0.030)$, IOP $(r=0.259, p=0.035), \operatorname{CDR}(r=0.348, p=0.004)$, and duration of type $2 \mathrm{DM}(r=0.364, p=0.003)$, while there are negative correlation $\mathrm{HbA} 1 \mathrm{c}$ level on RNFL $(r=-0.368, p=0.0002)$ and $\mathrm{MD}(r=-0.264, p=0.032)$. The LDL-C shows the positive and significant correlation on VA $(r=0.244, p=0.048)$, IOP $(r=0.335, p=0.006)$, CDR $(r=0.253, p=0.040)$, and duration of type 2 DM $(r=0.364, p=0.042)$ while there are negative and not significant correlation LDL-C level on RNFL ( $r=-0.024$, $p=0.848)$ and $\mathrm{MD}(r=-0.141, p=0.260)$.

\section{Discussion}

In this study, the majority of this patients are female $(71.2 \%)$, age range $43-79$ years old with the youngest age 43 years old and the oldest age 79 years old. Prabhavati study reported that female more suffering DM cause of female more to lose protection of blood vessels due to hormonal dysfunction in which correlated with estrogen deficiency, especially after menopause and the average of DM is $41-60$ years old [18]. The duration of suffering type 2 DM is $2-15$ years. The study reported found the risk of metabolic syndrome in younger age with suffering of type $2 \mathrm{DM}$ in longer duration [19], [20].

In this study, we found a significant correlation between levels of $\mathrm{HbA} 1 \mathrm{c}$ on VA, IOP, CDR, RNFL, $\mathrm{MD}$, and duration of type 2 DM. A study suggested that there was an increase in IOP in uncontrolled diabetics compared to those with controlled diabetes. The increase in glucose levels affects the synthesis of the excess extracellular matrix (ECM) in the trabecular meshwork cells results in the accumulation of ECM in the trabecular meshwork and causes obstruction of aqueous humor outflow. Another study found that there is a significant relationship between glaucomatous optic neuropathy and vascular disorders caused by increased HbA1c levels in patients with type 2 DM [14], [21]. 
Table 3: Correlation LDL-C level with VA, IOP, CDR, RNFL, perimetri MD, and duration of DM type 2

\begin{tabular}{|c|c|c|c|c|c|c|c|}
\hline \multirow[t]{2}{*}{ Variable } & \multicolumn{7}{|l|}{ LDL-C } \\
\hline & Optimal n (\%) & Near optimal n (\%) & Borderline $\mathrm{n}(\%)$ & High n (\%) & Very High n (\%) & Total n (\%) & $\mathrm{p}$ \\
\hline \multicolumn{8}{|l|}{ VA } \\
\hline$-0.2-0.1$ & $5(25.0)$ & $5(25.0)$ & $9(40.0)$ & $2(10.0)$ & 0 & $20(100.0)$ & \multirow[t]{4}{*}{$0.048^{*}$} \\
\hline $0.2-0.5$ & $5(35.7)$ & $4(28.6)$ & $5(35.7)$ & 0 & 0 & $14(100.0)$ & \\
\hline $0.6-0.9$ & $2(18.2)$ & $6(54.5)$ & 0 & $2(18.2)$ & $1(9.1)$ & $11(100.0)$ & \\
\hline $1.0-1.3$ & $4(19.0)$ & $5(23.8)$ & $4(19.0)$ & $5(23.8)$ & $3(14.3)$ & $21(100.0)$ & \\
\hline \multicolumn{8}{|l|}{ IOP } \\
\hline$\leq 21 \mathrm{mmHg}$ (normal) & $13(27.1)$ & 19 (39.6) & $14(29.2)$ & $1(2.1)$ & $1(2.1)$ & $48(100.0)$ & \multirow[t]{2}{*}{$0.000^{*}$} \\
\hline$>21 \mathrm{mmHg}$ (high) & $3(16.7)$ & $1(5.6)$ & $3(16.7)$ & $8(44.4)$ & $3(16.7)$ & $18(100.0)$ & \\
\hline \multicolumn{8}{|l|}{ CDR } \\
\hline Normal: $0.2-0.3$ & $1(25.0)$ & $2(50.0)$ & $1(25.0)$ & 0 & 0 & $4(100.0)$ & \multirow[t]{4}{*}{$0.040^{\star}$} \\
\hline Mild: $0.3-0.5$ & $12(31.6)$ & $9(23.7)$ & $12(31.6)$ & $4(10.5)$ & $1(2.6)$ & $38(100.0)$ & \\
\hline Moderate: $0.6-0.7$ & $3(15.8)$ & $5(26.3)$ & $3(15.8)$ & $5(26.3)$ & $3(15.8)$ & $19(100.0)$ & \\
\hline Severe: 0.8-1.0 & 0 & $4(80.0)$ & $1(20.0)$ & 0 & 0 & $5(100.0)$ & \\
\hline \multicolumn{8}{|l|}{ RNFL } \\
\hline Normal: >80nm & $6(27.3)$ & $7(31.8)$ & $7(31.8)$ & $2(9.1)$ & 0 & $22(100.0)$ & \multirow[t]{3}{*}{0.374} \\
\hline Borderline: 70-79nm & $2(10.0)$ & $9(45.0)$ & $4(20.0)$ & $3(15.0)$ & $2(10.0)$ & $20(100.0)$ & \\
\hline Outside normal: $<60 \mathrm{~nm}$ & $8(33.3)$ & $4(16.7)$ & $6(25.0)$ & $4(16.7)$ & $2(8.3)$ & $24(100.0)$ & \\
\hline \multicolumn{8}{|l|}{ MD Perimetri } \\
\hline Mild: >-6dB & $9(31.0)$ & $8(27.6)$ & $9(31.0)$ & $3(10.3)$ & 0 & $29(100.0)$ & \multirow[t]{3}{*}{$0.047^{*}$} \\
\hline Borderline: $-12<\mathrm{MD}<-6$ & $1(8.3)$ & $5(41.7)$ & $5(41.7)$ & $1(8.3)$ & 0 & $12(100.0)$ & \\
\hline Severe: $<-12 \mathrm{~dB}$ & $6(24.0)$ & $7(28.0)$ & $3(12.0)$ & $5(20.0)$ & $4(16,0)$ & $25(100.0)$ & \\
\hline \multicolumn{8}{|l|}{ Duration of DM } \\
\hline $\mathrm{DM} \leq 5$ years & $5(22.7)$ & $8(36.4)$ & $7(31.8)$ & $2(9.1)$ & 0 & $22(100.0)$ & \multirow[t]{3}{*}{$0.034^{*}$} \\
\hline DM 6-10 years & $11(33.3)$ & $9(27.3)$ & $8(24.2)$ & $2(6.1)$ & $3(9.1)$ & $33(100.0)$ & \\
\hline $\mathrm{DM}>10$ years & 0 & $3(27.3)$ & & $5(45.5)$ & $1(9.1)$ & $11(100.0)$ & \\
\hline
\end{tabular}

Table 4: Correlation HbA1c level and LDL-C level with VA, IOP, CDR, RNFL, Perimetri MD, and duration of DM type 2

\begin{tabular}{llllll}
\hline Variable & \multicolumn{2}{l}{ HbA1c } & & & LDL-C \\
\cline { 2 - 3 } & $\mathrm{R}$ & $\mathrm{P}$ & & $\mathrm{R}$ & $\mathrm{p}$ \\
\hline VA & 0.267 & $0.030^{*}$ & & 0.244 & $0.048^{*}$ \\
IOP & 0.259 & $0.035^{*}$ & & 0.335 & $0.006^{*}$ \\
CDR & 0.348 & $0.004^{*}$ & & 0.253 & $0.040^{*}$ \\
RNFL & -0.368 & $0.002^{*}$ & & -0.024 & 0.848 \\
MD Perimeter & -0.264 & $0.032^{*}$ & & -0.141 & 0.260 \\
Duration of DM & 0.364 & $0.003^{*}$ & & 0.251 & $0.042^{*}$ \\
\hline "Pearson correlation, significant<0.05, VA: Visual acuity, IOP: Intraocular pressure, CDR: Cup-to-disc ratio,
\end{tabular}

RNFL: Retinal nerve fiber layer, MD: Mean deviation, DM: Diabetes mellitus.

We also found a significant correlation between increased levels of LDL-C on VA, IOP, MD, and duration of type $2 \mathrm{DM}$. Several studies only reported a correlation between serum lipids and the incidence of glaucoma, but the correlation between serum lipids with glaucomatous optic neuropathy has never been found.

The current study found the positively correlation between higher $\mathrm{HbA} 1 \mathrm{c}$ as an indicator of glycemic control with VA $(r=0.267)$, IOP $(r=0.259)$, CDR $(r=0.348)$, duration of DM $(r=0.364)$ as a risk factor of glaucoma and negatively correlation of $\mathrm{HbA1C}$ on RNFL thickness $(r=-0.368)$ and $M D(r=-0.264)$, it means that higher $\mathrm{HbA} 1 \mathrm{c}$ level, the RNFL getting thinner, and the visual field $M D$ are getting worse. Evidence from another study found the positive association between glaucoma and $\mathrm{HbA} 1 \mathrm{c}$, suggesting that those with higher $\mathrm{HbA} 1 \mathrm{c}$ may be have a higher risk for developing glaucoma [20], [21]. A study found that the RNFL thinner had a positive correlation with vascular disease [20], [21]. We also found the positively correlation between higher LDL-C with VA $(r=0.244)$, IOP $(r=0.335)$, CDR $(r=0.253)$, and duration of DM $(r=0.251)$ as a risk factor of glaucoma. Foster found that higher LDL-C and HbA1c correlated with higher IOP on population based from age, sex, and blood pressure [22], but the correlation between $\mathrm{HbA1c}$ and LDL-C with glaucomatous optic neuropathy in type 2 DM has never been found. One of the pathogenesis of glaucoma in DM patients is an increase in systemic arterial pressure which causes a decrease in optic nerve blood flow and changes the optic nerve vascular environment cause insufficient blood supply to $\mathrm{ONH}$ and the axons of ganglion cells. Some studies showed that diabetes will lead to excessive fibronectin accumulation in the trabecular meshwork increased aqueous outflow. An increase in blood sugar levels can trigger an osmotic gradient so that fluids will shift to the intra ocular space resulting in an increase in IOP [23], [24]. Glucose interacts with free amino acid protein residues and ages can be deposited on the collagen artery walls and cause pathological cross-linking. Age-mediated cross links have high resistance to enzymatic proteolysis and low degradation rates, which may contribute to increased collagen content in arterial walls, characteristic in aging and accelerated in DM [25].

$A$ in vivo study showed that both increased IOP and visual field defects were significantly correlated with the degree of oxidative DNA damage. The relationship between oxidative stress and glaucoma to LDL/HDL has been a concern in various studies because of its antioxidant effects throughout the body [26].

\section{Conclusion}

Our findings reveal that subjects with higher $\mathrm{HbA1C}$ and LDL-C have correlation with higher IOP, thinner RNFL, loss of visual field defect MD as a risk factor of glaucomatous damage and correlated with duration of disease in type 2 DM. In the light of our findings and the evidence from the previous report, $\mathrm{HbA} 1 \mathrm{c}$ as an indicator of glycemic control in DM correlated with glaucomatous optic neuropathy.

Advantage of research is that glycemic control and LDL-C with glaucomatous optic neuropathy 
as a microvascular complication in type $2 \mathrm{DM}$ is still rarely studied. The limitation of this study, it was not population based but rather health center based, may cause a selection bias but further studies are needed to prospective longitudinal clinical trials on larger populations and longer more times to conclude another the risk factor and marker which correlated with quality of life in glaucoma.

\section{References}

1. Nanditha A, Ronald CW, Ramachandran A, Snehalatha C, Chan JC, Chia KS, et al. Diabetes in Asia and the pacific: Implications for the global epidemic. Diabetes Care J. 2016;39(3):472-85. https://doi.org/10.2337/dc15-1536 PMid:26908931

2. Sayin N, Kara N, Pekel G. Ocular complications of diabetes mellitus. World J Diabetes. 2015;6(1):92-108. PMid:25685281

3. American Diabetes Association. Diagnosis and classification of diabetes mellitus. Diabetes Care. 2008;31(1):562-7.

4. International Diabetes Federation. Diabetes Facts and Figures. IDF Diabetes Atlas $9^{\text {th }}$ ed. Belgium: International Diabetes Federation; 2019. https://doi.org/10.1016/ s1499-2671(08)24263-2

5. Perkumpulan Endokrinologi Indonesia. Konsensus Pengendalian dan Pencegahan Diabetes Mellitus Tipe 2 di Indonesia. Perkeni, Jakarta: Perkumpulan Endokrinologi Indonesia; 2016.

6. Aiello LP, Alejandro R, Alsahli M, Atkinson MA, Bode BW, Skyler JS, et al. Atlas of Diabetes. $4^{\text {th }}$ ed. Miami: Springer; 2012. p. 249-75.

7. Cantor LB, Rapuano CJ, Cioffi GA, editors. Association Glaucoma Section $10^{\text {th }}$. Introduction to Glaucoma: Terminology, Epidemiology, and Heredity. San Fransisco: American Academy of Ophthalmology the Eye MD; 2016. p. 20.

8. Quigley HA, Broman AT. The number of people with glaucoma worldwide in 2010 and 2020. Br J Ophthalmol. 2006;90(3):262-7. PMid: 16488940

9. Kemenkes RI. Situasi dan Analisis Glaukoma: Pusat Data Dan Informasi Kementerian Kesehatan RI. Jakarta: Kemenkes RI; 2015. https://doi.org/10.32922/jkp.v8i2

10. Riset Kesehatan Dasar. Gangguan Penglihatan dan Kebutaan di Indonesia. Badan Penelitian dan Pengembangan Kesehatan. Jakarta: Riset Kesehatan Dasar; 2007. https://doi.org/10.22435/ jpppk.v3i1.1882

11. Song JB, Aiello LP, Pasquale LR. Presence and risk factors for glaucoma in patients with diabetes. Curr Diab Rep. 2016;16(12):124. https://doi.org/10.1007/s11892-016-0815-6 PMid:27766584

12. Choi JA, Park YM, Han K, Lee J, Yun JS, Ko SH. Fasting plasma glucose level and the risk of open angle glaucoma: Nationwide population-based cohort study in Korea. PLoS One. 2020;9(23):e0239529. https://doi.org/10.1371/journal. pone.0239529

PMid:32966328
13. Pimentel LG, Gracitelli CP, da Silva LS, Souza AK, Prata TS Association between glucose levels and intraocular pressure: Pre-and post-prandial analysis in diabetic and nondiabetic patients. J Ophthalmol. 2015;2015:832058. https://doi. org/10.1155/2015/832058

\section{PMid:25642344}

14. Dube M, Chhawania PK, Shukla A, Kujur R. Correlation between serum lipids and primary open angle glaucoma: A clinical study. Delhi J Ophthalmol 2019;29:58-60. https://doi.org/10.7869/djo.444

15. Aref AA, Budenz DL. Spectral domain optical coherence tomography in the diagnosis and management of glaucoma. Ophthalmic Surg Lasers Imaging 2010;41:15-27. https://doi. org/10.3928/15428877-20101031-01

16. Khan MA, Rabeya MR, Saeidullah M. Measurements of HbA1c by high performance liquid chromatography in D-10 analyzer and immunological method by Beckman coulter AU480 system: A comparative study. J Enam Med Coll. 2012;2(2):62-6. https:// doi.org/10.3329/jemc.v2i2.12839

17. National Cholesterol Education Program. ATP III Guidelines at-a-Glance Quick Desk Reference. United States: Department of Health and Human Services; 2001.

18. Prabavathi K, Kunilkullaya KU, Goturu J. Glycosilated haemoglobin (HbA1c) a marker of circulating lipids in Type 2 diabetic patients. J Clin Diagn Res. 2014;8(2):20-3.

19. Luo M, Lim WY, Tan CS, Ning Y, Chia KS, van Dam RM, et al Longitudinal trends in $\mathrm{HbA} 1 \mathrm{c}$ and associations with comorbidity and all-cause mortality in Asian patients with Type 2 diabetics: A cohort study. Diabetes Res Clin Pract. 2017;133:69-77.

PMid:28898713

20. Hymowitz MB, Chang D, Feinberg EB, Roy S. Increased intraocular pressure and hyperglicemic level in diabetic patients. PLoS One. 2016;11(3):1-7. https://doi.org/10.1371/journal. pone.0151833 PMid:27002725

21. Jijeon S. Relationship between systemic vascular characteristic and RNFL loss in patients with Type2 diabetes. Sci Rep. 2018;8:10510

22. Foster PJ, Broadway C, Yip JL, Hayat S, Luben R, Dalzell N, et al. Serum lipids and glycated haemoglobin are associated with intraocular pressure in European people. Investig Ophthalmol Vis Sci. 2010;51(13):5829.

23. Oshitari T, Fujimoto N, Hanawa K, Adachi-Usami E, Roy S Effect of chronic hyperglycemia on intraocular pressure in patients with diabetes. Am J Ophthalmol. 2006;143(2):363-5. https://doi.org/10.1016/j.ajo.2006.09.033

PMid:17258539

24. Zhao D, Cho J, Kim MH, Friedman DS, Guallar E. Diabetes, fasting glucose and the risk of glaucoma: A meta-analysis. AAO J. 2015;122(1):72-8. https://doi.org/10.1016/j.ophtha.2014.07.051 PMid:25283061

25. Lonneville $\mathrm{YH}$, Ozdek SC, Onol M, Yetkin I, Gürelik G, Hasanreisoğlu B. The effect of blood glucose regulation on retinal nerve fiber layer thickness in diabetic patients. Ophthalmologica. 2003;217(5):347-50. https://doi.org/10.1159/000071350 PMid: 12913325

26. Sacca SC, Pascotto A, Caicione P, Capris P, Izzotti A Oxidative DNA damage in the human trabecular meshwork. Arch Ophthalmol. 2005;123(4):458-63. https://doi.org/10.1001/ archopht.123.4.458

PMid:15824217 